\title{
The Concept and Meaning of Gandang Sarunai Music as Reflected Through The Social and Cultural Activities of The Alam Surambi Sungai Pagu Community of South Solok District, West Sumatra
}

\author{
Esy Maestro \\ The Lecturer of Arts, Drama, Dance and Music \\ (Sendratasik) Department of FBS Universitas Negeri \\ Padang, Indonesia. \\ e-Mail: esymaestro@gmail.com
}

\author{
Marzam \\ The Lecturer of Arts, Drama, Dance and Music \\ (Sendratasik) Department of FBS Universitas Negeri \\ Padang, Indonesia. \\ e-Mail: marzam72@gmail.com
}

\section{Abstract}

Gandang Sarunai is a form of traditional Minangkabau music which lives, develops and grows in the daily life of the Alam Surambi Sungai Pagu community of South Solok District, West Sumatra. During the kingdom era when Alam Surambi Sugai Pagu was still led by kings, Gandang Sarunai music was acknowledged as the music of the kings. The performances of the gandang nobat repertoire and gandang puluik-puluik marked the coronation of the kings of Alam Surambi Sungai Pagu. At present, however, Raja Alam is no longer acting as the administrative leader of the community, but the head of the community's cultural affairs known as the penghulu, niniak mamak of the Alam Surambi Sungai Pagu community. Along with the changes of the king's roles, Gandang Sarunai has also experienced some role changes. Gandang Sarunai is now also performed in alek kawin and batagak panghulu festivals. Gandang Sarunai in this case, is seen by Keammer as an expression of how this traditional music is now valued pragmatically by its community, meaning that that the traditional music is now practiced for obtaining both material and moral benefits. In other words, Gandang Sarunai is now valued as more an expression of an adaptive culture than an expressive culture of the community of the Alam Surambi Sugai Pagu. Gandang Sarunai performances in the events like alek kawin and/or batagak panghulu festivals can be seen as a reflection of the community's efforts to strengthen their identity (clan, family), to raise their social status and to improve the community solidarity.

Keywords: gandang sarunai music, concept, and meaning

\section{INTRODUCTION}

Alam Surambi Sungai Pagu as a cultural area, is located in the District of Sungai Pagu, Kabupaten Solok Selatan, West Sumatra. The area is also known as "negeri seribu rumah gadang". As a cultural area, Alam Surambi Sungai Pagu certainly has a variety of customs such as music, dance, and other customs. The original music of Alam Surambi Sungai Pagu consists of; gontong-gontong, talempong pacik, saluang long, rabab, and gandang sarunai, while from the influence of Islamic, there are rabano, kasidah, and badikiu music.

The social and cultural activities of the Alam Surambi Sungai Pagu people, the coronation of the king, turun ke sawah, turun mandi anak, alek kawin, the circumcision, the welcoming of guests, the opening events, and the commemoration of the great days of Islam, are still presented although the Alam Surambi Sungai Pagu people have utilized the modern music such as; combo bands and single organs.

Gandang sarunai music performance in the social and cultural activities of Alam Surambi Pagu of South Solok regency basically is related to the concepts and meanings owned by the community. Based on the concept and meaning above-mentioned, the continuity of gandang sarunai music is still existed in every activity of their culture.

Today, gandang sarunai as the traditional music still persists and keep its continuity to be presented in every social and cultural activity even though the Western music performances enrich the cultural activities of Alam Surambi Pagu. It must be admitted that the intensity of gandang sarunai performance is no longer frequent since the Western music come in Alam Surambi Sungai Pagu. At this time, gandang sarunai musical performances both in the form of procession and in the original form (served sitting in an arena), are still found in alek kawin and batagak panghulu. Morover, someone who is as the event organizer also presents two genres of music. Western music (single organs) - is shown during the day, while gandang sarunai music is presented in the bridal procession (alek kawin) or the players sit and play it by sitting on an arena in the night.

Historically, gandang sarunai music was a kind of art that was concerned on the coronation process of king Raja Alam Surambi Sungai Pagu. The location of gandang sarunai music performance in traditional ceremonies of coronation process of King Alam was placed near the palaminan in front of the king, and this was required the slaughter of a buffalo. On that occasion, it was also presented the repertoire of gandang nobat and gandang puluik-puluik as symbol of king's inauguration. 
At that time, there were two kinds of musical instruments of gandang sarunai. The first is, musical instrument gandang sarunai that consists of two gandang namely, gandang jantan and gandang batino and sarunai. Second, the instrument of gandang sarunai music consists of gandang jantan, gandang batino, sarunai, and aguang. The last instrument that is explained before is rarely used because the instruments which use aguang are only allowed to be used in traditional ceremonies held by the royal family, while in the implementation of traditional ceremonies anak nagari, aguang is not allowed to be used according to customary provisions.

Today, the existence of gandang sarunai music in the social and cultural life of Alam Surambi Sungai Pagu has changed. Gandang sarunai music is no longer as the only aspect of supporting traditional activities and/or social and cultural activities that take place in the life of the community. Single Organ, has also become an option for the community to complete the customary activities and/or social and cultural activities.

When the members of each community celebrate alek kawin, some of them can present the two kinds of music. Gandang sarunai music is commonly presented at the night when some members prepare things such as cooking for ceremonial in for the next day. On the next day, when a bride goes to the Bako's house or when picking up the groom, gandang sarunai music is presented to accompany the procession. Meanwhile, single organ music has also been presented approximately from 10.00 a.m to 05.00 p.m as the entertainment for guests (Interviewed with Yasrial Katik Lembang Batuah, on October 14, 2016). For some who cannot use gandang sarunai, single organ music can be used.

Based on the condition above, the intensity of gandang sarunai music becomes decreased in the socio- cultural activities of Alam Surambi River Pagu community. It decreases but it is not lost like many cases occurred in several Minangkabau areas. Due to the popularity of single organs (modern music) in every activity of every customs and/or social and cultural activities, it impacts on the abandonment of traditional art that has been as the identity of the community. Such phenomena make the writers interested to discuss the concept and meaning of gandang sarunai music in the social and cultural activities of Alam Surambi Sungai Pagu Community of South Solok District, West Sumatra.

The study was included in the scope of art and culture studies. Concerning on the wide scope of culture in each community, this study was limited on exploring the concept and meaning of gandang sarunai music in community life. Therefore the scope discussed in this study was how the concept and meaning of the presence of gandang sarunai music so that the music persisted in every social and cultural activities of the community of Alam Surambi Sungai Pagu, South Sook District, West Sumatra.

To know the concept of gandang sarunai music as well as how it relates to the social and cultural activities of the community, Keammer (1993: 58) said that:

"The sociocultural matrix includes not only the social relationship between people and the standardized social institutions, but also the cultural concepts or understandings shared by people of a community. Many of these shared concepts relate to music, and they largely determine what people do musically. These concepts concern the values and motivations leading to musical performances, as well as the knowledge and skill necessary to produce and understand music."

The meaning of music is closely related to the concepts about music. However, people not only give the meaning to music, but they also use music to convey meaning. In this case, Keammer (1993: 108) states that:

"Meanings are essentially individual, but they become of interest to social science when they are shared among members of a social group. The meaning of music is broader than concepts about music because many of the meanings are not musical at all. Such meanings help explain why people engage in musical events and how musical behavior might produce certain musical styles."

Specifically Keammer (1993: 109) also revealed that:

"The meanings of music are basically of three types. Music often acquires meaning in terms of what it says, called symbolic or referential meaning. A second type of meaning, termed aesthetic, non-referential, or absolute, concern what music is-what the sounds convey without reference to anything else. In many societies the principal meaning of music is pragmatic, that is, it is used to obtain utilitarian benefits. Pragmatic meaning concern what music does. In the latter case, music is more closely related to adaptive culture than to expressive culture."

The rationale of the above-mentioned is used to describe and analyze the concept and meaning of gandang sarunai music performance in the life of Alam Surambi Sungai Pagu community today.

\section{Methodology}

This research is a qualitative research by using performance studies approach. The methods used in this research were descriptive, analytic, and interpretative method. The main data sources in qualitative research were the words and actions [primary data], and the rest were additional data such as documents and others (Moleong, 2012: 157). Data were collected 
through interviews, both formally and informally. During the interview, a tape recorder was used. In addition it was also photographed.

The object of this research was an event of musical performances, according to Santosa (2013: 231) the main approach used for this research was performance studies or the science of the show. The focus of this performance studies approach in the research was on ethnomusicology element because the object of the study was gandang sarunai music performance in the life of Alam Surambi Pagu community.

Ethnomusicology analysis was done to understand how the form of the dish and musical content in gandang sarunai music. So, it first took an understanding of the cultural context. Nettl (1964: 170) says, ...that music can be understood through a knowledge of its cultural context.

To obtain the results, all data was collected and processed, especially the data which was concerned in this research. In the data processing, it also used logical mind-set as intended by Muhadjir, (1990: 90-99), including: ... contextual mindset ... is a mindset that is concerned with the present, the present condition or situation; ... interpretive mindset ... capturing behind the sensual or superficial. Interpret to look for the meaning behind the explicit. Then, the processing of the data was supported by the review of library materials which were selected for it. Then to get the general arguments from the data that had been processed, it was used the inductive method that study a specific phenomena to get the principle that was applicable in the wider field.

\section{A. The Music of Gandang Sarunai in Alam Surambi Sungai Pagu}

\section{FINDING AND DISCUSSION}

The community of Alam Surambi holds to the customary words, such as rancak dek awak, katuju dek urang serta lamak dek awak, lamak dek urang. It means that between individuals and society, there is a mutual relationship. The interests of the individual are not located over the interests of the group/society, nor are the interests of the community are above the individual's interests. In this case, the individual realizes that being a free individual, s/he is also as a member of the community who participates in solving the problems that are occurred in his or her community. (Interview, Yasrial Katik Lembang Batuah, October 14, 2016).

The member of Sungai Pagu has responsibility to support the other members of the community, for example in carrying out the big celebrations such as alek kawin that usually include gandang sarunai music. The supports provided by community can be related to the material. Thus, they feel like they are as a family that can help each other. Meanwhile, the customs are based on the rules which are made by the Minangkabau ancestors in general. Katik Predi had explained about the rules and those can be seen as follows (Interview, Date October 13, 2016):

"In order for the development of society in line with the development of law which binds the unity of the Minangkabau society, the Minangkabau ancestors make this rules of life rule with the living words too. So it is known: adat nan babuhue mati, adat nan babuhue sentak, adat nan babuhue mati means the rules of life that cannot be changed for example sako turun ka kamanakan . adat nan babuhue sintak gives the freedom for the community to arrange their community without eny elements in forum (musyawarah"

The Minangkabau ancestors had made the rules to limit the habits done by the community. They made the rules of life that can be seen from the proverb "adat nan babuhue mati, adat nan babuhue sentak, adat nan babuhue mati "that cannot be changed for example "turun ka kamanakan" while "adat nan babuhue sentak" gives the freedom for the community to organize their members without ignoring the discussion (musyawarah).

Alam Surambi Sungai Pagu known as the kingdom of Sungai Pagu is the Ikua Darek of the Minangkabau Kingdom in Pagaruyung. In the book Alam Surambi Sungai Pagu and the book of Daily Puti Lelo Jati Bundo Kanduang Daulat Yang Dipertuan Bagindo Sultan Besar Tuanku Rajo Disambah In https: // id. wikipedia.org/wiki/Alam_Surambi_Sungai_Pagu (accessed on October 24, 2016), is explained that, there are four kings who lead the Kingdom of Alam Surambi Sungai Pagu (KASSP). Those are:

1. Daulat Yang Dipertuankan Bagindo Sultan Besar Tuanku Rajo Disambah (Rajo Daulat / Rajo Alam).

2. Tuanku Rajo Bagindo (Rajo adat, the master of Economics and Tambo Alam).

3. Tuanku Rajo Malenggang (taking care of Taxes in Banda nan Sapuluah/keeping the Palimo).

4. Tuanku Rajo Batuah (Rajo Ibadat, taking care, looking for the mines and the limit is until Sungai Abu dan Palangki).

The kings of nan- 4 are based on the head of each tribe of nan-4 KASSP. These four tribes have the greatness of ampek balai. Although the tribes are became the homebase of the kings of Nan-4, the tribes are not like the party which at the time the kings will be changed to the other successor. It means that each king has a strong position in the community. In sociohistorical structure, the organization of kings nan-4 are as a respected organization in the sub-district of KASSP. 
In the past, in each tribe, there are some members who were expert in playing gandang sarunai music. However, today, it is difficult to find out the people who master on it. From each tribe, it can be assumed that only one or two people who can play gandang sarunai music and even in each tribe, there is no one who are expert on playing gandang sarunai.

B. The Concept of Gandang Sarunai music performance

There are two levels of alek (party) in the social cultural activities held in Alam Surambi Sungai Pagu. The first level is alek bakajo, and the second is called the alek biaso. Alek Bakajo is done in the traditional ceremonies in giving title to Raja Adat or penghulu. This ceremony is better known as batagak panghulu ceremony. Meanwhile, alek biaso is the social cultural activities organized by society in general such as ceremony of marriage ceremony (alek kawin), batagak rumah ceremony, traditional ceremony of pangkas Gombak/cutting hair, and balimau ceremony.

According to Keammer (1993: 61), an important feature of the conceptual aspect of music is the way music is seen as fitting into a society's world view or general scheme of reality. Performing gandang sarunai, in this case batagak panghulu ceremony, according to Yasrial Katik Lembang Batuah (interview, October 14th, 2016), is marked by the fixing tabie in rumah gadang. Tabies are made from pieces of colorful fabrics dominated by black, red, and yellow colors. Tabie is fixed to cover the inner wall of the rumah gadang. Besides, it is also set about one hundred of marawa along the road.

Before the ceremony of batagak panghulu is held, firstly it must be done maurak lambai. This ceremony needs to be implemented because according to the rules rumah gadang, there are some important people who can enter rumah gadang. It means that only people who have permission can enter the entire rooms of rumah gadang.

This ceremony is usually performed approximately 15 days before alek bakajo or traditional ceremony of batagak panghulu is done. It is done because there are many works to do in rumah gadang in preparing the ceremony such as repairing the parts of rumah gadang and decorating the tabie, and any other works. At these moments, the rules prevailing in rumah gadang are temporarily wiped out.

The implementation of maurak lambai must be known by all members of the community, therefore the practice is done in the evening because at that time the whole community members are already in their homes.

On the day of the ceremony is performed, maurak lambai is take place in rumah gadang where the ceremony of batagak penghulu held. On this occasion, all members of the community have gathered in rumah gadang and gandang sarunai artists have also been present to perform their works to enliven the ceremony. Raja Adat will sit in front of the door of his nephew's room and express the poems According to the customary provisions, the poems that are said by Raja Adat can be seen as follows:

\author{
Buang batu buang kalapo, \\ Udanglah banyak di Pasie Talang. \\ Buang wakatu indak mangapo, \\ Rantau banyak bakeh layang.
}

Throw the stone away throw the coconut away,

There are plenty of Prawns in Pasie Gutters.

Wasting time does not matter,

There are some places to go

This proverb is usually answered by the niece of Raja Adat. However, the people in the community have cheered before the proverb is finished to be said. It is happened because the rhyming of that proverb is a symbol that lambai alah diurak. It means that the rules in the rumah gadang are not activated for a while.

The aim of this ceremony is to bring the cheerful in the community. At that time, the role of gandang sarunai music is very important. By presenting the music, the people who help who help the preparation of the ceremony are not quickly saturated and they are always in joy.

The custom ceremony of alek biaso is organized by Alam Surambi Sungai Pagu community. The types of traditional ceremonies of this alek biaso are the ceremony of marriage (alek kawin), batagak rumah, pangkas gombak (haircut), and balimau. The implementation of those types of traditional ceremonies mentioned above does not have to include the gandang sarunai music. However, if the community wants to present gandang sarunai music in their alek, the owner must first meet the requirements that have been determined by the custom for example slaughtering a cow.

In traditional marriage ceremonies (alek kawin), gandang sarunai is already presented at the time of slaughtering buffalo or cow. This buffalo or cow is slaughtered in the afternoon and later it is cooked for the needs of the members of the community who come to work in the evenings and the next day called malam bajago-jago.

Gandang sarunai music is begun when the cow is slaughtered. It aims to raise the spirit of community members who are working. Besides, the workers are not tired quickly because gandang sarunai music is played. After malam bajago-jago, gandang sarunai is presented again to entertain the people who come to work. 
When alek kawin is begun, gandang sarunai is played to accompany anak daro to the groom's house. This ceremony is called manjapuik marapulai. The music is played and it started from the bride's house to the groom's house. From the groom's house, the arak-arakan anak daro jo marapulai is implemented and gandang sarunai music is also played.

C. The Meaning of Gandang Sarunai Music performance

The meaning of music is closely related to the concept of music performance. Keammer (1993: 108) says "the meaning of music is broader than concepts about music because many of the meaning are not musical at all. Such meanings help explain why people engage in musical event..." Besides, he also says that:

In many societies the principal meaning of music is pragmatic, that is, it is used to obtain utilitarian benefits.

Pragmatic meaning concerns what music does. In the latter case, music is more closely related to adaptive culture than to expressive culture.

Organizing and participating in the activities of gandang sarunai music can be mean as the strengthening of identity for the members of Alam Surambi Sungai Pagu community. In line with Navis (1984: 118) who says that for the glory, it needs nak mulie batubue urai. The glory of the people or the person, it can be demonstrated during the performance of traditional ceremonies.

According to Yasrial Katik Lembang Batuah (interview, October 14, 2016), in the customary provisions it is mentioned that those who can perform traditional ceremonies involving gandang sarunai can be seen from the group of Malay Kampung Dalam or ethnic groups that have obtained the permission from the king. For groups of artists, their role in gandang sarunai music performance can be a pride because there are some people can play gandang sarunai music well. This group of artists, in the view of public, has a close relation with the royal family.

\section{CONCLUSION}

The music of gandang sarunai is the traditional music held in Alam Surambi Pagu whose existence is still alive. Gandang sarunai is not eroded by the rise of Western music that exists among Alam Surambi Pagu society. This is happened because there is still strong of traditional life that underlies the social life in Alam Surambi Sungai Pagu.

Raja Alam who has no longer administrative power, in the customary order and sociol-cultural life still remains a role as a model of society. It remains a pride for the community when they can engage in alek batagak panghulu or alek kawin which presents the music of rajo-rajo. Being able to present musical gandang sarunai in alek that they held is still perceived as strengthening their identity and / or family, thus indirectly it will raise their social status in the middle of their social life. When an alek is organized by presenting musical gandang sarunai, volunteers of other people of the community will come to help the implementation of the alek, which can be interpreted as a still high sense of solidarity owned by Alam Surambi Sungai Pagu community in general.

\section{References}

http://www.solselkab.go.id/post/read/154/sekilas-solok-selatan.html. Diakses tanggal 28 Maret 2016.

https://id.wikipedia.org/wiki/Alam_Surambi_Sungai_Pagu. Diakses tanggal 24 Oktober 2016.

Kaemmer, John E. (1993). Music in Human Life: Anthropological Perspectives on Music. Austin: University of Texas Press.

Moleong, Lexy J. (20120. Metodologi Penelitian Kualitatif. Edisi Revisi. Bandung: PT Remaja Rosdakarya.

Muhadjir, Noeng. (1996. Metode Penelitian Kualitatif. Edisi III. Cetakan 7. Yogyakarta: Penerbit Rake Sarasin.

Navis, A.A. (1984). Alam Takambang Jadi Guru Adat dan Kebudayaan Minangkabau. Jakarta: PT Grafiti Pers.

Nettl, Bruno. (1964). Theory and Method in Ethnomusicology. London: The Free Press of Glencoe Collier-Macmillan Limited.

Santosa, Djarot Heru. (2013). Seni Dolalak Purworejo Jawa Tengah: Peran Perempuan dan Pengaruh Islam dalam Seni Pertunjukan. Kawistara, Yogyakarta: Vol. 3, No. 3, Desember 2013. Hal. 227-241. 